\title{
STABLE BUSINESS POLICIES HELP IN ACHIEVING THE BUSINESS TARGETS: AN INVESTIGATION OF PRIMARY SCHOOLS BUSINESS IN DISTRICT CENTRAL, KARACHI, PAKISTAN
}

\author{
Muhammad Siddique* \\ Mariya Baig*** \\ Amar- ul- Haque ${ }^{* * *}$
}

\begin{abstract}
Expedition of the growth of a country's economy in the wake of entrepreneurial activity is significant. As skills are utilized and knowledge is applied, the entrepreneurs establish new businesses, and the enhancement of the latter is brought about through their sagacious decision-making and ingenuity. At one end, where entrepreneurial activities have been a boon to the societal progress; they have sped up development of economies worldwide. This can be attributed to a gamut of factors, which include, societies' expansion on the grounds of industrialization and urbanization; nurture of a culture of more information and awareness; formal training of the entrepreneurs; and, relaxed legal procedures. This study lays down emphasis on how upholding stable business policies can positively impact an entrepreneurial venture. Employing a well-developed and verified scale, data collection from 230 respondents was done on a convenience basis. The respondents chosen for this survey among whom the distribution of questionnaires was conducted were all situated in various localities of the District Central of Karachi, Pakistan; and descriptive statistics were applied on the variables pertinent for this study such as the establishment of stable business policies, continuation of the existing business policies, and achievement of the business targets based on the stable policies. It is intended that this research article shall serve to augment the scholarly literature that already exists on the subject matter that pinpoints the significance of the stable and continuous policies for an entrepreneurial business involved in the primary schooling businesses across the District Central of Karachi, Pakistan. This research paper addresses the need of having stable business policies for Pakistani entrepreneurs, and envisions itself to be one of the blueprints that can be considered by the relevant regulatory bodies while they make informed decisions. A well sketched out itinerary of initiatives could then be composed, which can assist in the meeting of the targets of entrepreneurial ventures, and eventually help in eradicating poverty from Pakistan.
\end{abstract}

Keywords: Business, stable policies, economic growth, skills and application of knowledge, entrepreneurial activities

This work is Licensed under a Creative Commons Attribution-Non-Commercial 4.0 International License. (c) (1) (8)

* Muhammad Siddique, Ph.D. Associate Professor, Pakistan Navy School of Logistics, PNS Karsaz, Karachi

${ }^{* * *}$ Mariya Baig, Ph.D. Pakistan Navy School of Logistics, PNS Karsaz, Karachi

**** Amar- ul- Haque, Research Scholar, C-78, Block-2, Saadi Town, Karachi, Pakistan 


\section{Introduction}

Entrepreneurship encapsulates within its notion the setting up of businesses from scratch and thereby, making profit at the expense of some financial risks. Therefore it can be said that that entrepreneurship is a vast concept that coalesces in it all such initiatives that involve discovery, evaluation, and exploitation of opportunities which are found in untraversed waters of human sphere of activity, with the hope of developing new businesses. There is an up shoot in the selling activates as market competition becomes more cut-throat on daily basis. As population of the world reaches a staggering number, there is increase in the needs of the people. In the same vein, Pakistan is also facing the pangs of overpopulation as the census of 2018 prods at the total population of Pakistan being around 202 million; majority of which live in its megacity of Karachi alone, where the population is about 16.1 million. A number of primary school owners are running their businesses in the District Central, Karachi. Out of these, only a few private educational institutions enjoy being undertaken by well experienced personal who practice effective policy implementation, and the rest of the primary schools, that can be classified as small and medium enterprises (SME) are at the stake of unstable business policies that offer no help in achieving the business targets.

The insignificant number of primary school business units that put to action stable business policies is an alarming indicator of future of economy of Pakistan. In majority of primary schools, the subordinates' work is never cross checked; business policies in the organizations are either not made or not firmly implemented, and in some cases, the policies are rapidly changed before their results can bear any result, thus handicapping these business units from achieving the set business targets. This kind of recklessness is detrimental to the said SMEs. Therefore, the entrepreneurs of primary schools should rely on stable business policies so that their businesses may easily achieve their targets and be able to reduce the losses.

The paragraphs that follow entail the literature that illuminate the importance of establishing stable business policies for small and medium enterprises. In the 3rd section, the research methodology used in the study is elaborated, which is followed by a discussion that elucidates the analysis of the results. Penultimately, the conclusion of the study has been laid down, which is succeeded by recommendations aimed at the addition to the body of knowledge.

\section{Research Background}

Most of the primary school businesses in Pakistan are started by people who have no prior experience. Although there are cases, where a little business experience is possessed by the entrepreneurs from the past when they worked briefly in the capacity of a teacher or an office bearer. Still, majority of the times, such entrepreneurs launch their primary school businesses lacking appropriate background and experience. Moreover, a large proportion of people involved in such businesses have limited to no awareness about the benefits of stable business policies for achieving the business targets of their organizations. Therefore, it is the extreme need to do research in this field. 


\section{Problem Statement}

The data collection process unearthed the ground reality that most of the entrepreneurs indulged running primary school businesses have insignificant business experience. The importance of stable business policies for their businesses is not known to them, neither are the benefits that can be reaped from instilling the practice of having stable business policies to meet the business targets. A proper research is hence essential for enlightening the entrepreneurs about the importance of stable business policies for small and medium enterprises.

\section{Research Question}

This study will unveil the ways in which primary school entrepreneurs can get over their uncertain business policy issues and make their business units become more targetoriented organizations. Is it true that the stable business policies of a business unit make an entrepreneurial business more target oriented?

\section{Objectives of the Study}

Principally, this study inherently has the objective to attempt to increase the awareness in primary school educationalists or entrepreneurs for keeping stable business policies so that they can easily and timely achieve their business targets.

\section{The Scope of the Study}

The scope of the study is to focus on the stable business policies of primary school entrepreneurial business units and to educate the entrepreneurs regarding the certain and stable business policies that are essential for target achievement.

\section{The Significance of the Study}

This research study endeavours the promotion of the requirement of stable business policies which are essential in the future growth of a primary school entrepreneurial business.

\section{The Beneficiary of the Study}

The primary school business is a very famous category of businesses in the society. Most of the educated and unemployed people can easily start this business easily and by keeping the stable business policies in the business, they can achieve the business targets in short time.

\section{Limitations}

Utmost efforts have been made by the researchers to include the opinions of the maximum respondents (primary school entrepreneurs) to address the maximum uncertain policy issues. The respondents' answers became the basis on which the researchers highly depended. The respondents or participants can never be hundred percent honest with their 
answers owing to various insecurities, etc. The chances of false or wrong answers may, indubitably, be there.

\section{Literature Review}

Kumar stated that there must be a continuousness in the approved business policies of the small and medium enterprises for a necessary period so that the predictable results may be achieved. ${ }^{1,2}$ AŠtrukelj et al.(2020) explained that the administration must provide a clear SME strategy to guide the SMEs in a particular direction for a certain period. ${ }^{3}$ Dierberger et al expressed that a stable policy is required to keep tasks the properly for achieving the targets as cited by ${ }^{4}$ Ziad Ali Eid Alshawabkeh et al. ${ }^{5}$ Akinso says that is essential that there must be clear policies and techniques for running such business effectively ${ }^{6}$ supported by Goodrich et al.and; Sunita Sanghi \& Srija, 2016; ${ }^{7}$ and Barringer ${ }^{8}$. Alauddin \& Chowdhury viewed that insecurity in government policies may cause to crush an enterprise business as often as possible government change its strategies in regards to expenses, and other essentials ${ }^{9}$ also expressed by Eniola \& Entebang ${ }^{10},{ }^{11}$

${ }^{1}$ Kumar, Vinod. "Business Policies and Management." International Journal for Science and Advance Research in Technology 6, no. 7 (2020): 588-99. https://doi.org/10.2307/1053074.

${ }^{2}$ Shafi, Mohsin, Junrong Liu, and Wenju Ren. "Impact of COVID-19 Pandemic on Micro, Small, and Medium-Sized Enterprises Operating in Pakistan.” Research in Globalization 2 (2020): 100018 https://doi.org/10.1016/j.resglo.2020.100018.

${ }^{3}$ Dierberger, George, Marc Isaacson, Cory Erickson, Thomas P Dierberger, and Business Executive. "Kissing Frogs : The Challenges Of Becoming A Successful Entrepreneur." The Journal of Applied Business Research 36, no. 2 (2020): 59-76.

${ }^{4}$ Ziad Ali Eid Alshawabkeh, Ziad Ali, Bassam Fathi Aldiabat, Mohammad A. Al-Zubeidi, Belal Hashem Nsour, Feras Suliman Al-Shalabi, Reham Zuheir Al-Momani, Khaled Banyhamdan, and Lina Hamdan Mahmoud Al-Abbadi. "Stability Strategy and Its Direct Role in Achieving Competitive Advantage at Jordanian Communication Companies." Academy of Strategic Management Journal 18, no. 3 (2019): 113.Ziad Ali Eid Alshawabkeh et al., "Stability Strategy and Its Direct Role in Achieving Competitive Advantage at Jordanian Communication Companies."

${ }^{5}$ Akinso, Ayodeji. "Successful Strategies for the Survival of Business Owners in Nigeria." Walden Dissertation and Doctoral Studies, Walden University, 2018.

https://scholarworks. waldenu.edu/cgi/viewcontent.cgi?article=6434\&context=dissertations\%0Ahttps://pdfs.se manticscholar.org/3ed4/b3a40b660edf7dac7382eabfedc09cb1d9a8.pdf?_ga=2.97563487.113908513.1581921 937-1515708840.1579295590.

${ }^{6}$ Goodrich, C G, K Gurung, P A Rizal, and S Silpakar. "Reflections on Policies for Women Small and Medium Entrepreneurs: Status, Challenges and Opportunities in the Hindu Kush Himalayas and the SAARC Region.” South Asian Women Development Forum, 2018.

http://www.academia.edu/download/57694540/Reflections_on_Policies_for_Women_Small_and_Medium_En trepreneurs_-_Hindu_Kush_Himalayas_and_the_SAARC__Region.pdf.

${ }^{7}$ Sunita Sanghi, -, and A Srija. "Entrepreneurship Development in India-the Focus on Start-Ups." Laugh Udyog Samachar, no. Special Article (2016): 20-27.

http://niti.gov.in/writereaddata/files/document_publication/MSME January 2016_0.pdf.

${ }^{8}$ Barringer, Bruce R. Entrepreneurship, 2016.

${ }^{9}$ Alauddin, Md., and Mustafa Manir Chowdhury. "Small and Medium Enterprise in Bangladesh-Prospects and Challenges." Global Journal of Management and Business Research: C Finance 15, no. 7 (2015): 11.

${ }^{10}$ Eniola, Anthony Abiodun, and Harry Entebang. "Government Policy and Performance of Small and

Medium Business Management." International Journal of Academic Research in Business and Social Sciences 5, no. 2 (2015): 237-48. https://doi.org/10.6007/ijarbss/v5-i2/1481.

${ }^{11}$ Tapera, Julius. "The Importance of Strategic Management to Business Organizations." Research Journal of Social Science \& Management 03, no. 11 (2014): 122-31.

https://www.researchgate.net/publication/301801352_The_Importance_of_Strategic_Management_to_Busines s_Organizations. 
Tapera explored that government conflicts may create policy making problems for the small and medium enterprises ${ }^{12}$ cited by Obaji and Olugu. It is noted that sometimes, small and medium business people have limited access to policymakers. ${ }^{13}$ Ahammad and Moudud-Ul- Huq cited that lack of access to data limits business working class's talented contribution to policymaking encouraged as supported by Abul Kashem et al ${ }^{14} \cdot{ }^{15}$ Ackah and Sylvester Vuvo stated that unfortunately, unfavorable business policies are the leading causes for the failure of SMEs. ${ }^{16}$ Sabbarwal explained that the success of an entrepreneurial business stable policymaking is the most important factor as cited by Teece ${ }^{17} \cdot{ }^{18}$ Roberts emphasized that there must be a stable political government in the nation that is able to design the strengthen policies for small and medium enterprises so that they may be able to achieve business targets as also expressed by Rocca et al ${ }^{19} .{ }^{20}$ Mitra further highlighted that stable policies act as the base for small and medium enterprises cited by Mustafa ${ }^{21} .{ }^{22}$ Haque emphasized that certainty in business policies are very essential for the success of a small and medium enterprise business ${ }^{23} \cdot{ }^{24}$ Beck \& Demirguc-kunt stated that good business policies of an entrepreneurship provide the road map of success to such business as supported by Hébert and Link ${ }^{25} .{ }^{26}$ Boberg et al further explained that stable business policies are very much important for a small and medium enterprise. ${ }^{27}$ Onugu also highlighted that the bad policies of an entrepreneurship always

${ }^{12}$ Obaji, Nkem Okpa, and Mercy Uche Olugu. "The Role of Government Policy in Entrepreneurship Development." Science Journal of Business and Management 2, no. 4 (2014): 109-15. https://doi.org/10.11648/j.sjbm.20140204.12.

${ }^{13}$ Ahammad, Issa, and Moudud-Ul- Huq. "Women Entrepreneurship Development in Bangladesh Challenges and Prospects." International Journal of Innovative Research \& Development 2, no. 7 (2013): 41-48.

${ }^{14}$ Abul Kashem, Md Ashadul Islam, and Md.Mohon. "Assignment on E Ntrepreneurship D Evelopment in B Angladesh." Entrepreneurship Development in Bangladesh Submitted. Bangladesh University of Business \& Technology (BUBT), 2012.

${ }^{15}$ Ackah, John, and Sylvester Vuvor. "The Challenges Faced by Small \& Medium Enterprises (SMEs) in Obtaining Credit in Ghana." School of Management, Ghana, 2011.

${ }^{16}$ Sabbarwal, Sherry. "Factors Affecting New Venture Creation: A Study in Indian Scenario.” International Journal of Business and Management Studies 2, no. 1 (2010): 81-88.

${ }^{17}$ Teece, David J. "Business Models, Business Strategy and Innovation.” Long Range Planning 43, no. 2-3 (2010): 172-94. https://doi.org/10.1016/j.lrp.2009.07.003.

${ }^{18}$ Roberts, Gregory John. "Entrepreneurship: An African Caribbbean Perspective," 2009.

${ }^{19}$ Rocca, M La, Tiziana La Rocca, and Alfio Cariola. "Small Business Financing. Financial Preferences throughout the Life Cycle of a Firm.” Spin off, Gender and Performance, no. August (2009): 1-31. http://www.efmaefm.org/0EFMAMeetingS/EFMA Annual Meeting/2009-

milan/EFMA2009_0476_fullpaper.pdf.

${ }^{20}$ Mitra, Jay. "Entrepreneurship Education in Pakistani Universities," 2008.

${ }^{21}$ Mustafa, Zahid. "Entrepreneurship and Microfinance- A Tool for Empowerment of Poor- Case of AkhuwatPakistan Thesis." Malardalen University, 2008.

${ }^{22}$ Haque, Nadeem Ul. "Entrepreneurship in Pakistan.” PIDE Working Papers, 2007.

${ }^{23}$ Organization, Asian Productivity. Entrepreneurship Development for Competitive Small and Medium Enterprise, 2007.

${ }^{24}$ Beck, Thorsten, and Asli Demirguc-kunt. "Small and Medium-Size Enterprises : Access to Finance as a Growth Constraint.” Journal of Banking \& Finance 30 (2006): 2931-43. https://doi.org/10.1016/j.jbankfin.2006.05.009.

${ }^{25}$ Hébert, Robert F., and Albert N. Link. "Historical Perspectives on the Entrepreneur." Foundations and Trends® in Entrepreneurship 2, no. 4 (2006): 261-408. https://doi.org/10.1561/0300000008.

${ }^{26}$ Boberg, Katarina, Monika Nowak, and Annika Olsson. "The Relationship between Management Accounting and Entrepreneurial Orientation." Management Accounting and Entrepreneurship, 2005 ${ }^{27}$ Onugu, B.A.N. "Small and Medium Enterprises (SMEs) in Nigeria: Problems and Prospects." PhD Thesis. ST. Clements University, 2005. 
create the big problems for a business that is cited by Manisha Devendrabhai Thaker ${ }^{28}$ and Hopp ${ }^{29} .{ }^{30}$ Malik also reported that stable policies provide the guidelines to a business for setting its business goals and targets viewed by Saemundsson ${ }^{31}{ }^{32}$ Schaper further stated that good business policies always act as the helping tools for a business as expressed by Manzur-ul-Haq ${ }^{33} \cdot{ }^{34}$ According to Manzur-ul-Haq that due stable policies of a business, it can meets its offered targets to the customers, also cited by Newton ${ }^{35}$.

\section{Conceptual Framework}

Based on the study of relevant articles in the literature review, the researchers have designed the conceptual framework as under:

\section{INDEPENDENT VARIABLES}

Timely Records Management

\section{DEPENDENT VARIABLE}

Entrepreneurial Businesses (Primary School Business)

Figure-1: Conceptual Framework

\section{Hypotheses}

$\mathrm{H} 1_{0}$ : Entrepreneurial business performance has no association with stable business policies.

$\mathrm{H} 1_{\mathrm{A}}$ : Entrepreneurial business performance has positive association with stable business policies.

\section{Descriptive Analysis of Alternate $\left(\mathrm{H}_{1 \mathrm{~A}}\right)$ Hypothesis}

It indicates a strong association of an entrepreneurial business performance with the caring of stable business policies in a business. It means that for achieving timely business targets having the stable business policies are most important for an entrepreneurial business. Therefore, it is true that having the stable business policies in

${ }^{28}$ Manisha Devendra Bhai Thaker. "Problems and Prospects of Tourism Industry in Gujrat," 2004.

${ }^{29}$ Hopp, Stefan. "J. B. Say's 1803 Treatise and the Coordination of Economic Activity." BERG Working Paper Series on Government and Growth 47, no. 47 (2004). http://www.uni-

bamberg.de/sowi/economics/wenzel/berg.

${ }^{30}$ Malik, Muhammad Iqbal. "Pakistan: An Entrepreneurial Vacuum," 2003.

${ }^{31}$ Saemundsson, R J. "Entrepreneurship, Technology and the Growth Process: A Study of Young, MediumSized Technology-Based Firms." Doktorsavhandlingar Vid Chalmers Tekniska Hogskola. Chalmers

University of Technology, Sweden, 2003. https://www.google.com/search?sourc.

${ }^{32}$ Schaper, Michael. "The Future Prospects for Entrepreneurship in Papua New Guinea." Journal of Small Business Management 40, no. 1 (2002): 78-83.

${ }^{33}$ Gurbiel, Roman. "Impact of Innovation and Technology Transfer of Economic Growth : The Central and Eastern Europe Experience." Center of International Production Cooperation 162, no. July (2002): 1-18.

${ }^{34}$ Manzur-ul-Haq. "Entrepreneurship, Private Investment and Economic Growth." The Lahore Journal of Economics, no. Special Edition (2001): 18

${ }^{35}$ Newton, Keith. "Management Skills for Small Business," 2001. 
a business makes an entrepreneurial business as target oriented and target achieving business.

\section{Research Methodology Population}

The population of this study based on the primary schools situated in district central of Karachi. The district central areas consists of Liaquatabad Town, North Nazimabad Town, Gulberg Town and New Karachi Town.

\section{Sampling Technique}

For data collection, the purposive sampling method for convenience was adopted and data was collected from where it was easy for the researchers. It is the general observation that in Pakistani society the percentage of research oriented people is very less because the majority of the people are unaware from significance of research. They hesitate to disclose the business data, and secondly, every entrepreneur does not participate in fulfilling the questionnaire. From a total of 250 questionnaires, only 230 valid questionnaires received back.

\section{Sample Size}

The accepted sample size for the study is 230 because the researchers received back only 230 questionnaires out of 250 questionnaires after an assigned period of 20 days that the participants demanded for completion of the task.

\section{Data Collection Technique and Instrument}

The researchers used a well-structured and verified scale to gather statistics for the study. For data collection purposes, the researchers personally distributed the questionnaires among the respondents engaged in the different primary school running business in district central of Karachi. The data collected from different schools situated in the study area of the city. Subsequently, the collected data then analyzed by using the statistical tools.

\section{Reliability Test}

The researchers applied Cronbach's Alpha to check the reliability of the questionnaire and its internal consistency. The rate of Cronbach's Alpha was 0.708. It is suggested the accepted edge of reliability should be at least 0.70 . It shows that the tool use $d$ for the research is reliable. The questionnaire was also validated from field experts.

\section{Data Analysis and Findings}

This section covers two parts. Part-A represents the data demographics, while Part-B represents the data analysis of the study. 


\section{PART-A}

\section{Data Demographics}

In this part, the demographic section of the respondents has been addressed. Here, five main areas of respondents have been checked. The records as per data collected from the study area consist of gender, age, education, experiences, and strength of the respondents. The detailed discussion on these five elements have been given in the following paragraphs:

\begin{tabular}{|l|c|r|r|r|r|}
\hline \multicolumn{7}{|c|}{ Descriptive Statistics } \\
\hline & N & Minimum & Maximum & Mean & Std. Deviation \\
\hline Age & 230 & 22.00 & 57.00 & 38.352 & 10.403 \\
\hline Gender & 230 & 1.00 & 2.00 & 1.600 & 0.491 \\
\hline Education & 230 & 3.00 & 5.00 & 3.809 & 0.723 \\
\hline Experience & 230 & 2.00 & 15.00 & 7.844 & 3.212 \\
\hline Number of Employees & 230 & 2.00 & 20.00 & 13.231 & 3.537 \\
\hline Valid N (list wise) & 230 & & & & \\
\hline
\end{tabular}

\section{Gender}

This study exclusively consists of 230 primary schools situated in central of Karachi city. Schooling is a business of responsibilities and regularity. This business demands patience and waiting for having the positive results. That is why the majority of ladies are managing the school business in Pakistan because it is observed that they are more responsible and concentrated to their business as compare to men.

\section{Age}

Figure_2, below, depicts that the age of respondents is between 24 years to 75 years. It is a very respectable business and people like it due to the reason that these institutions not only develop but improves the behavior of young generation. Age details of respondents accompanied with respective percentages are given in fig._2 
Figure_2: Age of respondents

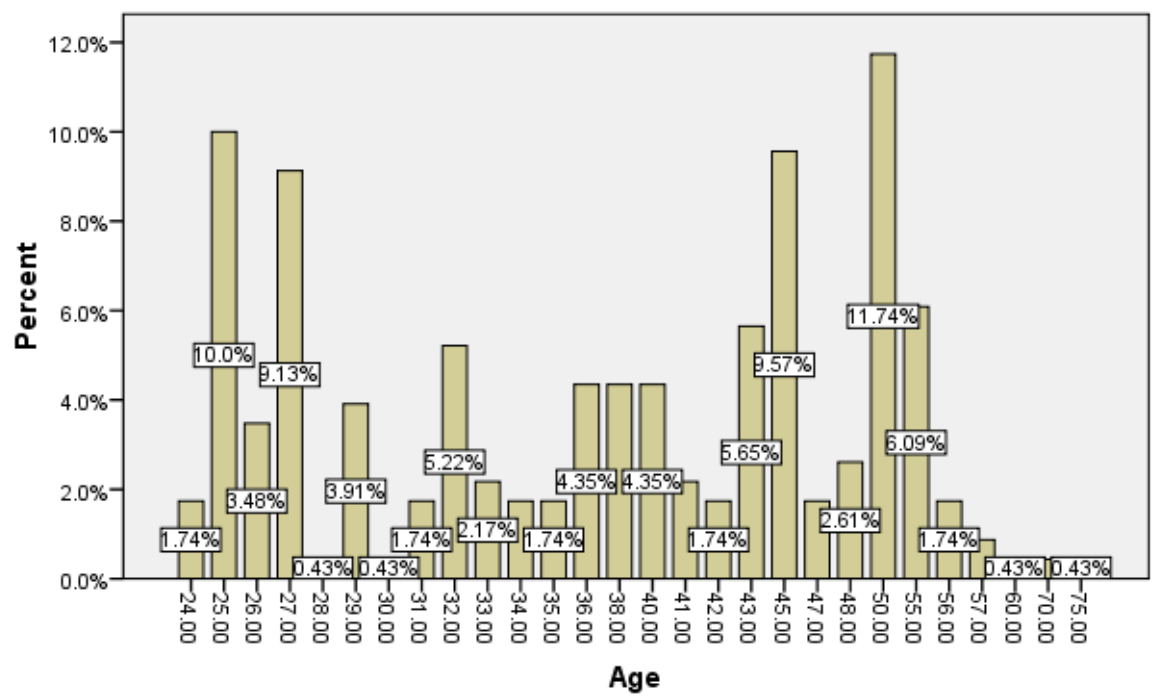

Stable Business Policies Help in Achieving the Business Targets

\section{Education}

Figure_3 represents the education of respondents. Accordingly, 37.4\% respondents were just intermediate who were running the primary schools in the sample area, $44.3 \%$ were graduate and $18.3 \%$ respondents were post graduates only. It shows that in Pakistan, majority of females and some males start this business after marriage. The reason is that when after a lot of efforts they remained unable to find a suitable job they start this business. But in some cases they establish this business in the beginning with their interest of due to family background. Following is the graphical details of education of respondents in the sample area of district central in Karachi, Pakistan. 
Figure_3: Education of respondents

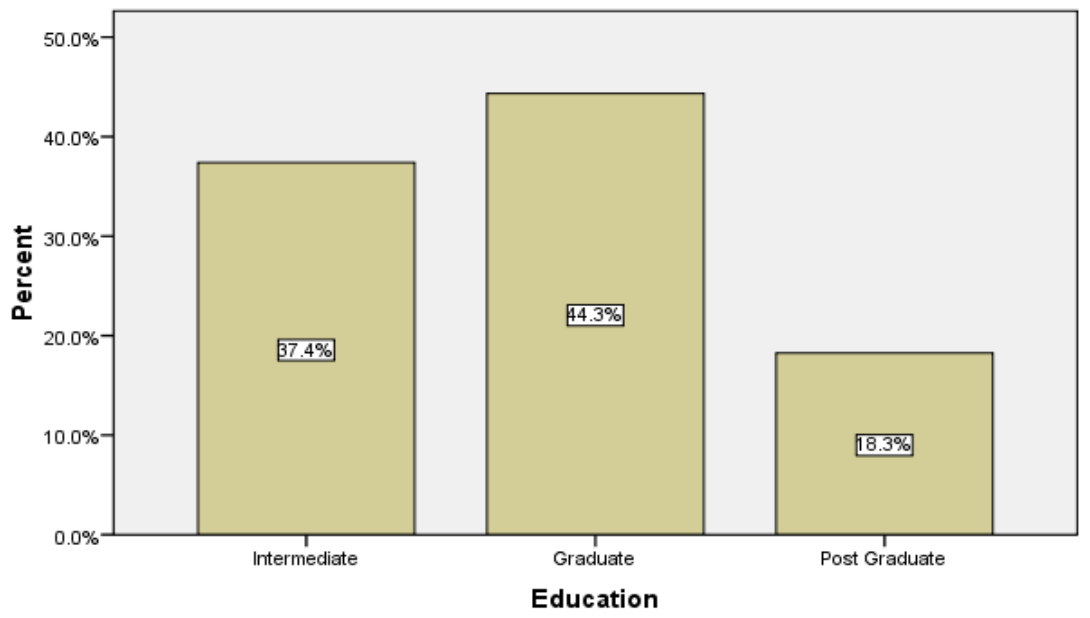

Stable Business Policies Help in Achieving the Business Targets

\section{Experience}

Figure_4: depicts the experiences of respondents in the sample area. Accordingly, 1.3\% of primary school owners are new and they have business experience of only 2 years. The $0.43 \%$ primary school owners have experience of 19 years. Fig._4, shows the record of experience of the respondents got from the study area.

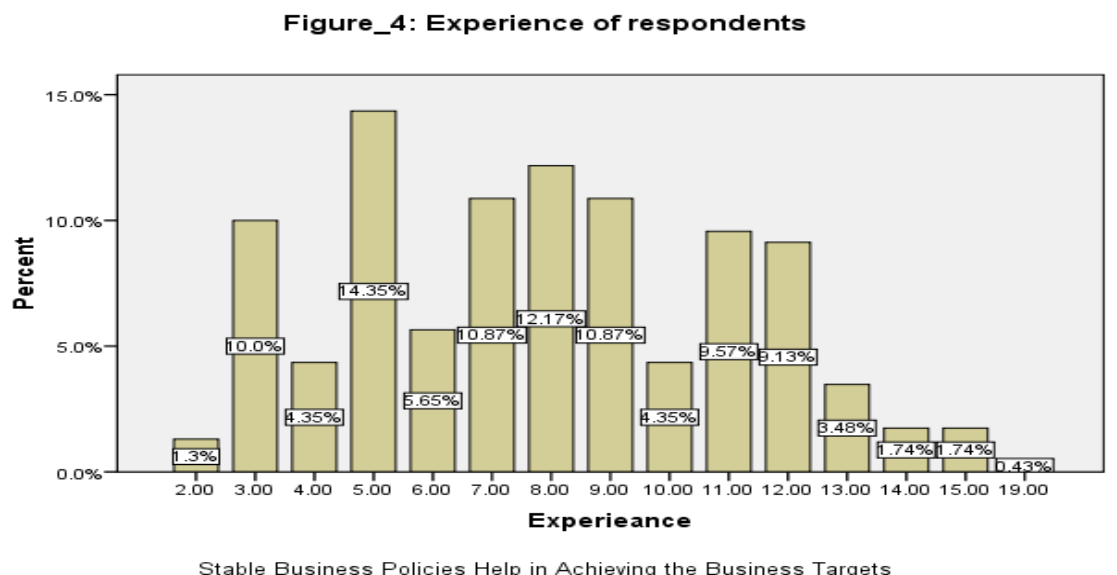




\section{Strength (Number of respondents)}

A total of 230 primary schools teachers and owners participated in questionnaire filling process in the sample area. Figure_5 shows the strength of primary schools staff in the sample areas. As per graphical representation, there are 7 to 20 staff were running such schools in the sample area of this research paper.

Figure_5: Strength of respondents

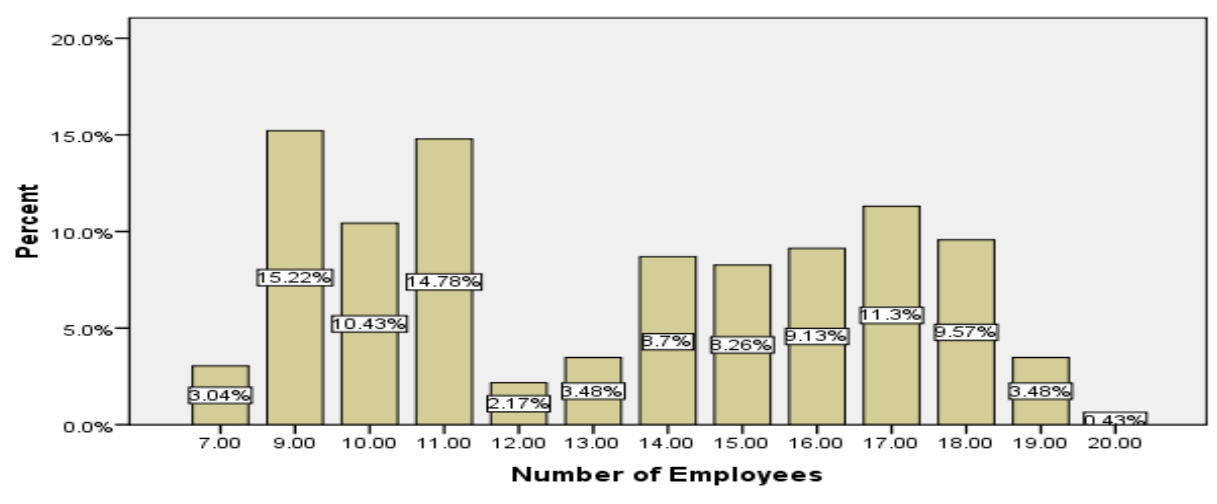

Stable Business Policies Help in Achieving the Business Targets

\section{PART-B}

\section{Data Analysis}

This section consists of different figures that indicating the analysis done by the Statistical Package for Social Sciences (SPSS) and a discussion of findings accordingly. 


\section{The Stable Business Policies}

Figure_6: Stable_Business_Policies
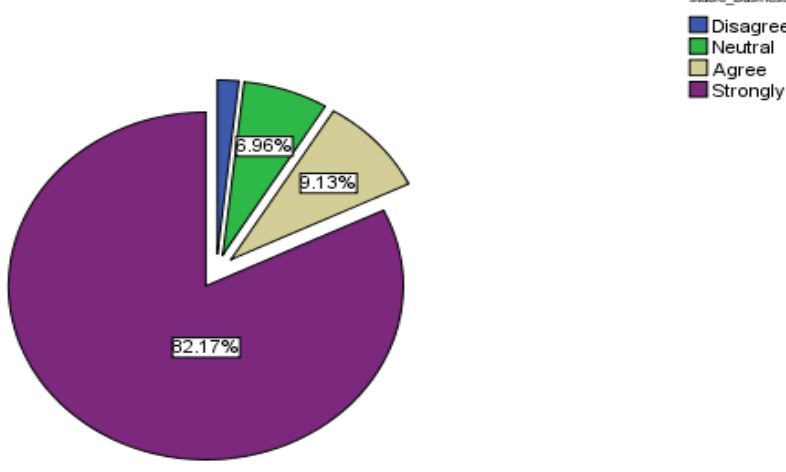

Agree

Agree

Stable Business Policies Help in Achieving the Business Targets

Figure_6, shows that $82.17 \%$ of the targeted population strongly agreed with the fact that there must be continue and stable policy system in an entrepreneurial business such as of primary schools. 9.13\% people agreed with this concept. It means overall $91.3 \%$ of the target population voted for stable policy system in a business. $6.96 \%$ people remained neutral while only $1.74 \%$ participants disagreed with this concept. It shows that the majority of people were in favor of the topic chosen for research.

\section{Meeting the Business Targets}

It is true that stable business policies help in meeting the business targets that are essential for meeting the customer demand. $75.22 \%$ people strongly agreed with this concept especially for the primary school business in the district central of Karachi in targeted area. $19.57 \%$ people agreed with this idea while $3.48 \%$ people did not vote to this need and only $1.73 \%$ people disagreed with this idea as graphically indicated by figure_7, below: 


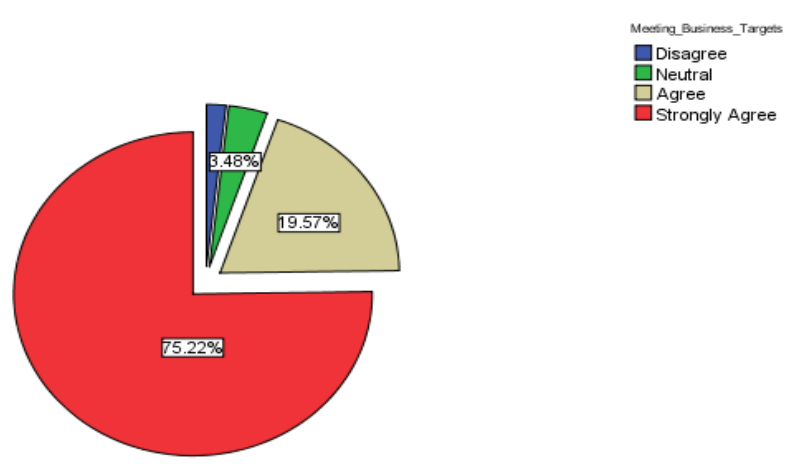

Stable Business Policies Help in Achieving the Business Targets

\section{Variation in Business Policies}

According to figured_8, 49.57\% of the target population strongly agreed with the concept that if the existing business policies in organizations such as primary schools' business are not stable and they show a variation in them, such businesses may not be able to meet their business targets in time and the customers of these organizations will never be happy with them. $37.83 \%$ of the targeted population agreed with this idea while $11.74 \%$ respondents remained neutral and only $0.86 \%$ papulation disagreed with the idea.

Figure_8: Variation_In_Business_Policies
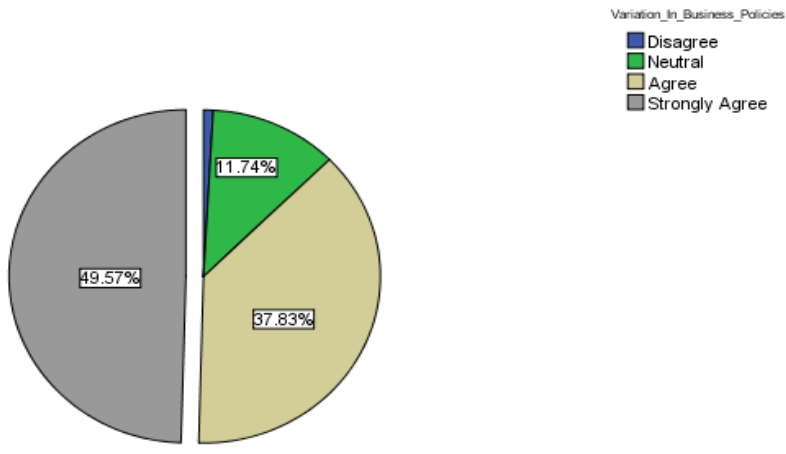


\section{Conclusions}

Based on data analysis and discussion, it is concluded that stable business policies not only improve the business results but they help in achieving the business targets as per demand. It helps in developing a long term and proper system for the business in future. An entrepreneur must consider the following factors for the better performance for a small business:

The Stable Business Policies: To keep the business affairs in a right and positive direction it is necessary that the business policies of such organizations such as primary schools must be stable and firm because in this way such businesses may perform as per their decided future plans.

Meeting the Business Targets: The stable and continued business policies always help in achieving the timely business targets that increase the peoples' trust on such organizations.

Variation in Business Policies: The organizations such as primary schools' due variation in their policies may lose their business because this habit may weak the trust of parents on such schools and ultimately people will withdraw their children from such schools and this type of actions may create hurdle for such entrepreneurial business in future.

\section{Recommendations}

The proposed recommendations for the study are:

Based on the results achieved from the analysis, having stable business policies for primary schools are very important for their progress and prosperity.

Stable business policies justify to recommend for primary schools business because they can get the trust of parents as well as students due to such policies and they will be able to make better plans for their better future.

It is therefore recommended that stable business policies for primary schools may help them in achieving their business targets in time and may compete in the field easily if they do not change their business policies in short periods of time especially in the district central of Karachi, Pakistan.

\section{Bibliography}

Abul Kashem, Md Ashadul Islam, and Md.Mohon. "Assignment on E Ntrepreneurship D Evelopment in B Angladesh." Entrepreneurship Development in Bangladesh Submitted. Bangladesh University of Business \& Technology (BUBT), 2012.

Ackah, John, and Sylvester Vuvor. "The Challenges Faced by Small \& Medium Enterprises ( SMEs ) in Obtaining Credit in Ghana ." School of Management, Ghana, 2011. 
Ahammad, Issa, and Moudud-Ul- Huq. "Women Entrepreneurship Development In Bangladesh Challenges And Prospects." International Journal of Innovative Research \& Development 2, no. 7 (2013): 41-48.

Akinso, Ayodeji. "Successful Strategies for the Survival of Business Owners in Nigeria." Walden Dissertation and Doctoral Studies, Walden University, 2018. https://scholarworks. waldenu.edu/cgi/viewcontent.cgi?article=6434\&context=dissertatio ns\%0Ahttps://pdfs.semanticscholar.org/3ed4/b3a40b660edf7dac7382eabfedc09cb1d9a8 .pdf?_ga=2.97563487.113908513.1581921937-1515708840.1579295590.

Alauddin, Md., and Mustafa Manir Chowdhury. "Small and Medium Enterprise in Bangladesh-Prospects and Challenges." Global Journal of Management and Business Research: C Finance 15, no. 7 (2015): 11.

Barringer, Bruce R. Entrepreneurship, 2016.

Beck, Thorsten, and Asli Demirguc-kunt. "Small and Medium-Size Enterprises : Access to Finance as a Growth Constraint." Journal of Banking \& Finance 30 (2006): 2931-43. https://doi.org/10.1016/j.jbankfin.2006.05.009.

Boberg, Katarina, Monika Nowak, and Annika Olsson. "The Relationship between Management Accounting and Entrepreneurial Orientation." Management Accounting and Entrepreneurship, 2005.

Dierberger, George, Marc Isaacson, Cory Erickson, Thomas P Dierberger, and Business Executive. "Kissing Frogs : The Challenges Of Becoming A Successful Entrepreneur." The Journal of Applied Business Research 36, no. 2 (2020): 59-76.

Eniola, Anthony Abiodun, and Harry Entebang. "Government Policy and Performance of Small and Medium Business Management." International Journal of Academic Research in Business and Social Sciences 5, no. 2 (2015): 237-48. https://doi.org/10.6007/ijarbss/v5-i2/1481.

Goodrich, C G, K Gurung, P A Rizal, and S Silpakar. "Reflections on Policies for Women Small and Medium Entrepreneurs: Status, Challenges and Opportunities in the Hindu Kush Himalayas and the SAARC Region.” South Asian Women Development Forum, 2018.

http://www.academia.edu/download/57694540/Reflections_on_Policies_for_Women_S mall_and_Medium_Entrepreneurs_-

__Hindu_Kush_Himalayas_and_the_SAARC_Region.pdf.

Gurbiel, Roman. "Impact of Innovationnd Technology Transfer of Economic Growth : The Central and Eastern Europe Experience." Center of International Production Cooperation 162, no. July (2002): 1-18.

Haque, Nadeem Ul. “Entrepreneurship in Pakistan.” PIDE Working Papers, 2007.

Hébert, Robert F., and Albert N. Link. "Historical Perspectives on the Entrepreneur." Foundations and Trends® in Entrepreneurship 2, no. 4 (2006): 261-408. https://doi.org/10.1561/0300000008. 
Hopp, Stefan. "J. B. Say's 1803 Treatise and the Coordination of Economic Activity." BERG Working Paper Series on Government and Growth 47, no. 47 (2004). http://www.uni-bamberg.de/sowi/economics/wenzel/berg.

Kumar, Vinod. "Business Policies and Management." International Journal for Science and Advance Research in Technology 6, no. 7 (2020): 588-99.

https://doi.org/10.2307/1053074.

Malik, Muhammad Iqbal. "Pakistan: An Entrepreneurial Vacuum,” 2003.

Manisha Devendrabhai Thaker. ““ Problems and Prospects of Toursim Industry in Gujrat,"” 2004.

Manzur-ul-Haq. "Entrepreneurship, Private Investment and Economic Growth." The Lahore Journal of Economics, no. Special Edition (2001): 18.

Mitra, Jay. "Entrepreneurship Education in Pakistani Universities,” 2008.

Mustafa, Zahid. "Entrepreneurship and Microfinance- A Tool for Empowerment of Poor- Case of Akhuwat-Pakistan Thesis." Malardalen University, 2008.

Newton, Keith. "Management Skills for Small Business,” 2001.

Obaji, Nkem Okpa, and Mercy Uche Olugu. "The Role of Government Policy in Entrepreneurship Development." Science Journal of Business and Management 2, no. 4 (2014): 109-15. https://doi.org/10.11648/j.sjbm.20140204.12.

Onugu, B.A.N. "Small and Medium Enterprises (SMEs) in Nigeria: Problems and Prospects.” PhD Thesis. ST. Clements University, 2005.

Organization, Asian Productivity. Entrepreneurship Development for Competitive Small and Medium Enterprise, 2007.

Roberts, Gregory John. "Entrepreneurship : An African Caribbbean Perspective,” 2009.

Rocca, M La, Tiziana La Rocca, and Alfio Cariola. "Small Business Financing. Financial Preferences throughout the Life Cycle of a Firm." Spin off, Gender and Performance, no. August (2009): 1-31.

http://www.efmaefm.org/0EFMAMeetingS/EFMA Annual Meeting/2009-

milan/EFMA2009_0476_fullpaper.pdf.

Sabbarwal, Sherry. "Factors Affecting New Venture Creation: A Stuy in Indian Scenario." International Journal of Business and Management Studies 2, no. 1 (2010): 81-88.

Saemundsson, R J. "Entrepreneurship, Technology and the Growth Process: A Study of Young, Medium-Sized Technology-Based Firms." Doktorsavhandlingar Vid Chalmers Tekniska Hogskola. Chalmers University of Technology, Sweden, 2003. https://www.google.com/search?sourc.

Schaper, Michael. "The Future Prospects for Entrepreneurship in Papua New Guinea." 
Journal of Small Business Management 40, no. 1 (2002): 78-83.

Shafi, Mohsin, Junrong Liu, and Wenju Ren. "Impact of COVID-19 Pandemic on Micro, Small, and Medium-Sized Enterprises Operating in Pakistan." Research in Globalization 2 (2020): 100018. https://doi.org/10.1016/j.resglo.2020.100018.

Sunita Sanghi, -, and A Srija. "Entrepreneurship Development in India-the Focus on Start-Ups.” Laugh Udyog Samachar, no. Special Article (2016): 20-27.

http://niti.gov.in/writereaddata/files/document_publication/MSME January 2016_0.pdf.

Tapera, Julius. "The Importance of Strategic Management to Business Organizations." Research Journal of Social Science \& Management 03, no. 11 (2014): 122-31. https://www.researchgate.net/publication/301801352_The_Importance_of_Strategic_Ma nagement_to_Business_Organizations.

Teece, David J. "Business Models, Business Strategy and Innovation." Long Range Planning 43, no. 2-3 (2010): 172-94. https://doi.org/10.1016/j.lrp.2009.07.003.

Ziad Ali Eid Alshawabkeh, Ziad Ali, Bassam Fathi Aldiabat, Mohammad A. AlZubeidi, Belal Hashem Nsour, Feras Suliman Al-Shalabi, Reham Zuheir Al-Momani, Khaled Banyhamdan, and Lina Hamdan Mahmoud Al-Abbadi. "Stability Strategy and Its Direct Role in Achieving Competitive Advantage at Jordanian Communication Companies." Academy of Strategic Management Journal 18, no. 3 (2019): 1-13. 